\title{
WOBWLABE SDLUIDAS
}

\section{Using Lockout and Tagout Procedures to Prevent Injury and Death during Machine Maintenance}

\section{Summary}

Workers are at risk of severe injury and death during machine maintenance and servicing if proper lockout and tagout procedures are not followed. NIOSH recommends developing and implementing a hazardous energy control program including lockout and tagout procedures and worker training to prevent such incidents.

\section{Description of Exposure}

Machine-related injuries or fatalities can occur during maintenance and servicing tasks when workers are exposed to an uncontrolled release of energy or during unexpected equipment startup. During 1982-2006, $\mathrm{NIOSH}$ investigated 185 fatalities related to installation, maintenance, service, or repair tasks on or near machines, equipment, processes, or systems. Investigations were carried out in 20 States as part of the Fatality Assessment and Control Evaluation (FACE) Program. Failure to completely de-energize, block, and/ or dissipate the energy source was a factor in 142 (77\%) of the incidents; failure to lockout and tagout energy control devices and isolation points after de-energization was a factor in 31 (17\%). If machines start up during maintenance, repair, adjusting, or servicing, workers can be caught in the machinery and suffer fractures, crushing injuries, amputations, or death [NIOSH 1999, 2006].

\section{Application of the Lockout/Tagout Standard}

Incidents related to lockout/tagout procedures were the most cited violation in manufacturing by the Occupational Safety and Health Administration (OSHA) during 2006-2007 [Jarrell and Washam 2009]. One study analyzed OSHA accident investigation reports from 1984-1997 and found that in more than half of the 348 investigated cases, lockout procedures were "not even attempted" [Bulzacchelli et al. 2008]. These figures reinforce the necessity of having a written hazardous energy control program and ensuring that employees understand and follow the procedures.

Lockout/tagout procedures APPLY in the following circumstances:

- Workers are servicing and maintaining equipment, and unexpected startup of the machine or release of stored energy could occur [Jarrell and Washam 2009]

- When, during normal production, workers must remove or bypass a guard or safety device [Jarrell and Washam 2009]

- When, during normal production, workers place any part of their body into the danger zone or near the machine's point of operation [OSHA 2002]

- During all set up activities [Jarrell and Washam 2009]
DEPARTMENT OF HEALTH AND HUMAN SERVICES Centers for Disease Control and Prevention National Institute for Occupational Safety and Health

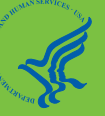

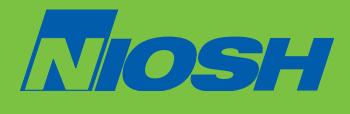




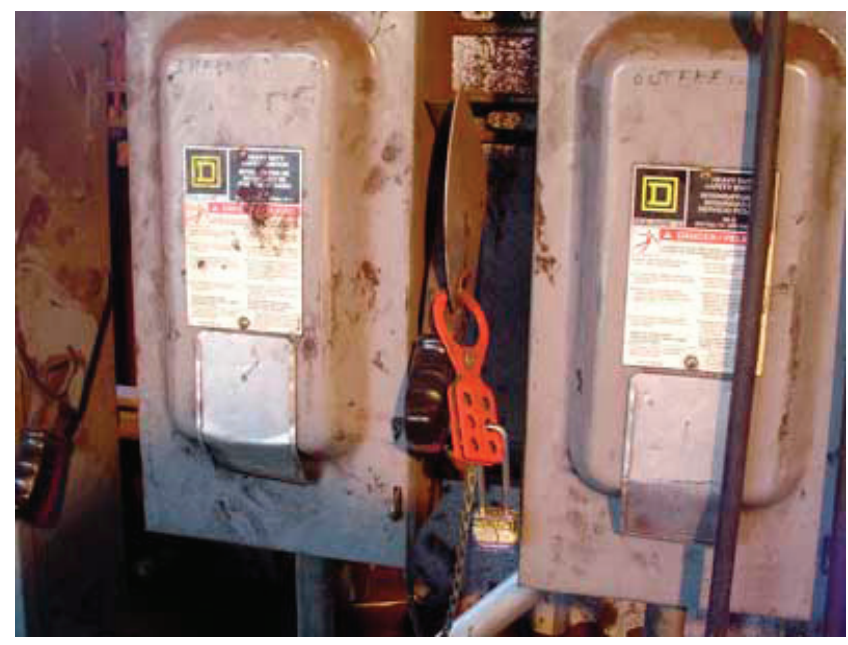

Figure 1. This photo illustrates the south debarker room where locks had been placed on two electrical circuits by the victim [Photo courtesy of SCOSHA].

\section{Case Report}

The NIOSH FACE program investigated the following incident in which a millwright was fatally injured because of an uncontrolled release of energy while he was repairing a debarker [NIOSH 2006]:

The teeth on the debarker feed rolls had become worn, and the worker had been assigned to weld additional metal to build up the feed roll teeth. He had not conducted this type of repair before.

To safely de-energize this machine, six electrical sources and one pneumatic energy source needed to be disconnected and locked out, and the pressure in the air line that automatically controls the up and down motion of the feed rolls needed to be bled off. The victim disconnected and locked out two of the electrical sources (See Figure 1), but he did not disconnect and lock out the other four electrical sources or the pneumatic energy source, and he did not bleed off the pressure in the air lines. In this condition, the machine's automatic control system remained energized. As the victim welded metal to the feed roll teeth, he leaned forward and placed his head between the feed rolls to reach areas that required more metal. The feed rolls automatically cycled, and closed over his head.

His supervisor had left to check on another machine and when he returned, he found the millwright caught in the machine. Emergency medical services personnel arrived 20 minutes after receiving the 911 call and attempted cardiopulmonary resuscitation, but the millwright had died.
The millwright had been trained in general lockout/tagout procedures on the job, but the procedures failed to address the following:

- The use of locks to ensure that the electrical sources remain disconnected

- The disconnect locations for the six electrical energy sources and one pneumatic energy source for the debarker

- Procedures for bleeding, blocking, and verifying that stored pneumatic energy (air pressure) had been rendered safe

- Clearly labeling each lock with a durable tag (or durable label or marking) to identify the worker assigned to a lock that is used to secure an energy control device

\section{Recommendations}

NIOSH recommends that employers and workers take the following steps to prevent machine-related injuries:

\section{Employers}

NIOSH recommends that employers comply with the OSHA regulations outlined in $29 \mathrm{CFR}^{*} 1910.147$, the control of hazardous energy (lockout/tagout). Results of NIOSH fatality investigations indicate that the following steps are particularly important.

- Develop and implement a written hazardous energy control program, including lockout/tagout procedures, employee training, and inspections before any maintenance or service work is done [NIOSH 1999].

- Be sure that workers have a clear understanding of when hazardous energy control procedures apply and training on how to properly apply the procedures.

- Ensure that procedures on lockout/tagout are developed that are specific to each machine [NIOSH 2006; Michalscheck 2008].

- Provide training to production workers in addition to maintenance workers in methods of energy isolation and control [see 29 CFR 1910.147(b)].

- To effectively isolate each energy source, ensure that workers are provided with a sufficient number of lockouts and tagouts and other hardware that may be needed [See 29 CFR 1910.147(c)(5)(i)].

- Clearly label isolation devices, such as breaker panels and control valves [NIOSH 1999].

- After removing the lockout or tagout devices but before starting the machine, be sure that all employees who

${ }^{*}$ Code of Federal Regulations. See CFR in References. 
operate or work with the machine, as well as those in the area where service or maintenance is performed, know that the devices have been removed and that the machine is capable of being re-energized [OSHA 2002; 29 CFR Part 1910.147 (e)(3)].

- Ensure that no one under the age of 18 works on machinery declared hazardous in the Child Labor Rules [29 CFR 570.120].

- Ensure that workers receive training in their primary language.

\section{Workers}

- Follow the regulations contained in your employer's hazardous energy control program.

- Complete all employer-provided training on hazardous energy control procedures.

- Before beginning machine adjustment, maintenance, or servicing work, do the following [NIOSH 1999]:

1. De-energize all sources of hazardous energy:

- Disconnect or shut down engines or motors.

- De-energize electrical circuits.

- Block fluid (gas or liquid) flow in hydraulic or pneumatic systems.

- Block machine parts against motion.

2. Lockout and tagout all forms of hazardous energy, including electrical breaker panels and control valves. ${ }^{\dagger}$

3. Block or dissipate stored energy:

- Discharge capacitors.

- Release or block springs that are under compression or tension.

- Vent fluids from pressure vessels, tanks, or accumulators, but never vent toxic, flammable, or explosive substances directly into the atmosphere.

- Make sure that only one key exists for each of your assigned locks and that only you hold that key."

- Verify by test and/or observation that all energy sources are de-energized.

OSHA standards require the use of either lockout or tagout. However, NIOSH [1999] recommends that any hazardous control program include both to ensure maximum protection. Also note that some State plans may have more stringent requirements than those found in 29 CFR 1910.147.

* Use of master keys should be reserved for unusual circumstances when the worker is absent from the workplace. However, if master keys are necessary, keep them under supervisory control. List the proper procedures for using them in the written program for controlling hazardous energy.
- Inspect repair work before removing your lock and activating the equipment.

- Make sure that only you remove your assigned lock.

- Make sure that you and your coworkers are clear of danger points before re-energizing the system (see 29 CFR 1910.147(e) and 29 CFR 1910.117(f).

\section{Manufacturers}

Consider designing equipment that requires fewer and more easily accessible disconnect points to facilitate the use of safe lockout/tagout procedures for maintenance and repair [NIOSH 2006].

\section{OSHA Information}

For information about energy control procedures, protective equipment, inspection, and training, see (http://www. osha.gov/pls/oshaweb/owadisp.show_document?p_ table=STANDARDS\&p_id=9804). OSHA has a Lockout-Tagout Interactive Training Program that can be useful in better understanding the requirements of the OSHA hazardous energy control standard (http://www. osha.gov/dts/osta/lototraining/index.html ).

\section{Acknowledgments}

This document was developed by Susan Afanuh, Education and Information Division (NIOSH); and Paul Moore and Tim Pizatella, Division of Safety Research (NIOSH).

\section{References}

Bulzacchelli MT, Vernick JS, Sorock GS, Webster, DW, Lees PSJ [2008]. Circumstances of fatal lockout/tagout-related injuries in manufacturing. Am J Ind Med 51:728-734.

CFR. Code of Federal regulations. Washington, DC: U.S. Government Printing Office, Office of the Federal Register. Jarrell JL, Washam J [2009]. Lockout/tagout: controlling hazardous energy to prevent workplace injury. Washington, DC: OSHA Training and Education Directorate, OSHA Course No. 7115.

Michalscheck J [2008]. Lockout/tagout: are the hazards misunderstood? EHS Today Dec: 38-43. http://ehstoday.com/safety/best-practices/lockouttagout_hazards_misunderstood/

NIOSH [1999]. NIOSH Alert: preventing worker deaths from uncontrolled release of electrical, mechanical, and other types of hazardous energy. Cincinnati, OH: U.S. Department of Health and Human Services, Centers for Disease Control and Prevention, National Institute for Occupational Safety and Health, DHHS (NIOSH) Publication No. 99-110. http://www.cdc.gov/niosh/docs/99-110/ 
DEPARTMENT OF HEALTH AND HUMAN SERVICES

Centers for Disease Control and Prevention

National Institute for Occupational Safety and Health

4676 Columbia Parkway

Cincinnati, $\mathrm{OH}$ 45226-1998

Official Business

Penalty for Private Use $\$ 300$

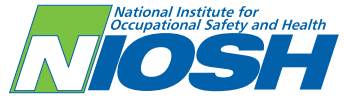

NIOSH [2006]. Millwright killed when pinned between the feed rolls of a debarker during machine maintenanceSouth Carolina. Morgantown, WV: U.S. Department of Health and Human Services, Centers for Disease Control and Prevention, National Institute for Occupational Safety and Health, DHHS (NIOSH) FACE Report 2006-02. http:// www.cdc.gov/niosh/face/In-house/full200602.html

OSHA [2002]. Control of hazardous energy: lockout/tagout (2002 Revised). Washington, DC: U.S. Department of Labor, Occupational Safety and Health Administration.

\section{For More Information}

The information in this document is based on field research and FACE reports. More information about the FACE program is available at http://www.cdc.gov/niosh/face/.

To receive NIOSH documents or more information about occupational safety and health topics, please contact NIOSH at

Telephone: 1-800-CDC-INFO (1-800-232-4636)

TTY: 1-888-232-6348 • E-mail: cdcinfo@cdc.gov or visit the NIOSH Web site at www.cdc.gov/niosh

For a monthly update on news at NIOSH, subscribe to NIOSH eNews by visiting www.cdc.gov/niosh/eNews.

Mention of any company or product does not constitute endorsement by NIOSH. In addition, citations to Web sites external to NIOSH do not constitute NIOSH endorsement of the sponsoring organizations or their programs or products. Furthermore, NIOSH is not responsible for the content of these Web sites. :
This document is in the public domain and may be freely copied or reprinted. NIOSH encourages all readers of the Workplace Solutions to make them available to all interested employers and workers.

As part of the Centers for Disease Control and Prevention, NIOSH is the Federal agency responsible for conducting research and making recommendations to prevent work-related illnesses and injuries. All Workplace Solutions are based on research studies that show how worker exposures to hazardous agents or activities can be significantly reduced.

\section{Using Lockout and Tagout Procedures to Prevent} Injury and Death during Machine Maintenance

\section{DHHS (NIOSH) Publication No. 2011-156}

